\title{
STATE PROPERTY MANAGEMENT: STATISTICAL PORTRAIT NOVELTIES
}

A new indicator framework for the performance measurement of state property management was adopted early last year. Basic characteristics of state property and of economic entities that are in state ownership have been presented on the basis of the initial data gathered from the framework. Transition to providing data in terms of legal forms, which was not the case under the old indicator framework for public sector monitoring, as well as a special focus on property (real estate, land, stakes (interest) of any size) given the value and liquidity thereof is the main novelty that the new framework offers.

The data obtained from the indicator framework for the performance measurement of state property management were first published in the last spring. The framework was adopted by Russian Government's Executive Order No. 72 of 29 January 2015 in replacement for a indicator framework for public sector monitoring that the Federal State Statistics Service (Rosstat) employed since the start of the 2000s pursuant to Russian Government's Executive Order No. 1 of 4 January 1999 (as amended on 30 December 2002). Serious changes have taken place with regard to the population of economic entities that are monitored with the purpose of assembling of statistical data (Table 1).

With great generality of the public sector in the old definition and in the new array of indicators, one cannot but note the absence of public sector's essential element such as business entities in which public sector business entities held a stake (interest) of more than $50 \%$, which limits the stakeholding comparison with the data for the previous years (Table 2).

According to the data obtained from the new framework, the number of economic entities that are in state ownership totalled approximately 65,600 by the start of 2016, which is 1,000 above the public sector monitoring data released two years ago, but it is about 540 below the number reported in the mid-2013.

Note an increase in comparable categories of economic entities compared with the most recent data of the public sector monitoring as of the mid-2014, the number of government agencies increased about 2,500 (or 4.6\%) while the number of state unitary enterprises (SUEs) was up about 50 (or 1.1\%), and the number of government entities by the start of 2016 was found to even outnumber the number seen three years ago. It is difficult to make any conclusions about business entities because the old and the new frameworks are incompatible in terms of this category. What is obvious is that their total number (about 3,900 ) by the start of 2016 outnumbered the number $(3,500)$ of business entities in which the state held a controlling stake (interest) by the start of 2013 .

1 The most recent public sector development bulletin covered the period between January and September 2014, but the semi-annual data as of 1 July 2014 are quite useful for a medium term analysis. 


\section{COMPARISON LIST OF ECONOMIC ENTITIES SUBJECT TO STATISTICAL SURVEY IN TERMS OF STATE PROPERTY MANAGEMENT}

\begin{tabular}{|c|c|c|c|}
\hline \multirow[b]{2}{*}{$\begin{array}{l}\text { Category } \\
\text { of entities }\end{array}$} & \multicolumn{2}{|c|}{ Source of information } & \multirow[b]{2}{*}{$\begin{array}{l}\text { Changes in composi- } \\
\text { tion of monitored enti- } \\
\text { ties and measurement }\end{array}$} \\
\hline & $\begin{array}{l}\text { List of entities for public } \\
\text { sector ownership, 1999 } \\
\text { (as amended in 2002) }\end{array}$ & $\begin{array}{l}\text { indicator framework for } \\
\text { the performance measure- } \\
\text { ment of state property } \\
\text { management, } 2015\end{array}$ & \\
\hline $\begin{array}{l}\text { State unitary enter- } \\
\text { prises, including state- } \\
\text { owned enterprises }\end{array}$ & $\begin{array}{c}\text { such enterprises were listed } \\
\text { (state-owned enterprises were } \\
\text { not indicated separately) }\end{array}$ & $\begin{array}{l}\text { such enterprises are listed } \\
\text { (state-owned enterprises } \\
\text { are indicated separately) }\end{array}$ & small breakdown \\
\hline Government entities & $\begin{array}{l}\text { such entities were listed } \\
\text { (autonomous, state-funded, } \\
\text { state-owned entities were } \\
\text { not indicated separately) }\end{array}$ & $\begin{array}{c}\text { such entities are listed } \\
\text { (autonomous, state-funded, } \\
\text { state-owned entities are } \\
\text { indicated separately) }\end{array}$ & detailed breakdown \\
\hline $\begin{array}{l}\text { Business entities with } \\
\text { state participation }\end{array}$ & $\begin{array}{l}\text { only business entities in which } \\
\text { the state held a stake } \\
\text { (interest) of more than } \\
50 \% \text { were listed }\end{array}$ & $\begin{array}{l}\text { business entities in which } \\
\text { the state holds a stake (inter- } \\
\text { est) of any size are listed }\end{array}$ & $\begin{array}{l}\text { Total coverage that includes } \\
\text { all cases of government } \\
\text { shareholding, but overes- } \\
\text { timates state's control via } \\
\text { minority stakes (interest) }\end{array}$ \\
\hline $\begin{array}{l}\text { Business entities in } \\
\text { which public sec- } \\
\text { tor business entities } \\
\text { hold a stake (interest) } \\
\text { of more than } 50 \%\end{array}$ & $\begin{array}{l}\text { were available since } \\
\text { c } 2003\end{array}$ & available & $\begin{array}{l}\text { an essential component that } \\
\text { previously allowed to gain } \\
\text { a certain impression of the } \\
\text { scope of state's indirect par- } \\
\text { ticipation in the economy } \\
\text { has been excluded from the } \\
\text { statistical survey system }\end{array}$ \\
\hline $\begin{array}{l}\text { Joint-stock companies } \\
\text { in which the Russian } \\
\text { Federation or subjects } \\
\text { thereof enjoy a spe- } \\
\text { cial right to partake in } \\
\text { corporate governance } \\
\text { ("golden share") }\end{array}$ & $\mathrm{n} / \mathrm{a}$ & available & $\begin{array}{l}\text { A certain clarification has been } \\
\text { made to gain impression of } \\
\text { the scope of using an indirect } \\
\text { tool of state property control }\end{array}$ \\
\hline
\end{tabular}

NUMBER OF PUBLIC SECTOR ORGANIZATIONS THAT ARE REGISTERED

WITH THE FEDERAL AGENCY FOR STATE PROPERTY MANAGEMENT, LOCAL OFFICES THEREOF AND STATE PROPERTY MANAGEMENT AGENCIES OF SUBJECTS OF THE RUSSIAN FEDERATION, IN 2013-2014 AND NUMBER OF ECONOMIC ENTITIES THAT ARE IN STATE OWNERSHIP AS OF 1 JANUARY 2016 (ACCORDING TO STATE REGISTRATION DATA) ACCORDING TO THEIR LEGAL STATUS

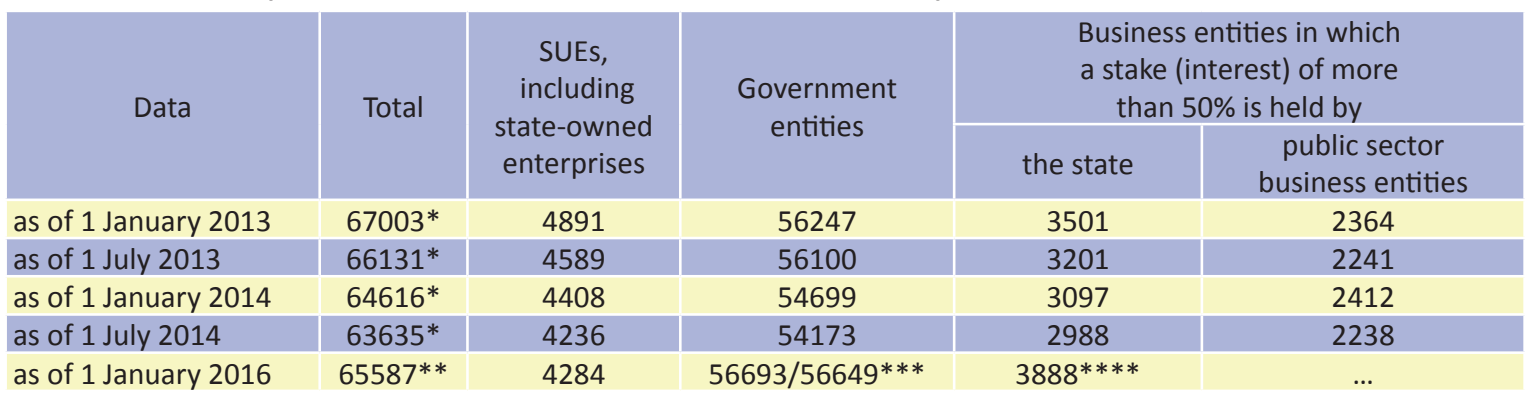

* including organizations whose state registered articles of association do not provide specific types, but excluding joint-stock companies in which a stake (interest) of more than $50 \%$ is jointly held by the state and foreign companies;

** including more than 760 economic entities whose legal status differs from that of unitary enterprises, government entities and business entities (Table 3);

*** excluding 2 state academies of sciences and 42 private entities that pertain to entities under the new framework but must be excluded in order to ensure that the comparison is correct;

**** total regardless of the size of a state-held stake (interest), no data on the number of business entities that are fully owned by the state are available.

Source: On the development of the public sector of the Russian Federation in 2012 (pp. 7-11), in H1 2013 (pp. 7-11), 2013 (pp. 7-11), in H1 2014 (pp. 7-11), M., Rosstat, 2013-2014, www.gks.ru, 20 March 2016. 
The new indicator framework for the performance measurement of state property management and statistical survey formation includes 64 indicators divided into five sections as follows:

I. Structure of economic entities that are in state ownership (with breakdown into data on the Russian Federation and subjects thereof);

II. Management of JSCs whose shares are the property of the federal government, federal state unitary enterprises (FSUEs) and federal government entities (FGEs) (with breakdown into 3 respective sub-sections);

III. Privatization of federally owned property;

IV. Management of federal real property (with breakdown into 2 sub-sections: land plots and other real property);

V. Redistribution of federal real property, including various levels of public legal entities.

It is difficult to classify the specified set of indicators.

Semantically, it is obviously distinguished by general quantitative indicators that reflect the scope (number) of a given type of state-owned assets ${ }^{1}$ that are differentiated by specific features (e.g., by type of economic activity, type of unitary enterprises, type and departmental affiliation of entities, size of a federally held stake (interest) and availability in the lists adopted by Russian Government's Executive Order No. 91- $p^{2}$ (for JSCs) of 23 January 2003, federal treasury status (for federal real property other than land)). The indicator of absolute quantity of federal lands that are registered as the property owned by the Russian Federation is complemented with area size data (with breakdown into categories of users and legal regimes that govern access to land) and valuation.

Indicators that describe the status and functioning of economic entities that use state-owned assets, but only at the federal level, are of importance.

They refer to a wide range of indicators of financial and business operations of JSCs with state participation, FSUEs and FGEs (profit (loss) size and net asset value (applicable only to JSCs and FSUEs), fixed asset assessment (full book value and net book value, depreciation of fixed assets, the share of fully depreciated fixed assets (the latter is applicable only to JSCs and FSUEs)), accounts payable and receivable (applicable only to JSCs and FSUEs), number of employees (applicable only to FSUEs and FGEs) and payroll size). Technically, this can also include indicators such as the share of profit- and loss-making JSCs and FSUEs, but in the adopted indicator framework they are brought beyond the scope of the block of indicators of financial and economic activities, being adjacent to budget revenues generated from such assets, i.e., to resulting indicators.

Note that indicators that describe the state property management mechanism appear to be in overwhelming minority. This refers to only two indicators: (1) number of professional directors elected as members of governing bodies of joint-stock companies whose shares are the property of the federal government, by category (independent directors and professional agents), with separation of a group of JSCs enrolled in special lists, as well as (2) the share of tenders for sale of the right to enter into leasehold agreements on real property that are in state ownership, on which information is posted on

1 This is how exactly the term "quantitative indicator" should be understood, because any indicator includes a quantitative aspect.

2 A JSC in which the position of the state as shareholder on a series of essential issues is determined at government level (hereinafter - "the special list"). 
an information and communication network such as the Internet (www.torgi. gov.ru).

It would be logical to include various types of federal budget revenue generated from the use of state property (dividends on shares, transfer of a share of profits of unitary enterprises, revenue from lease of property that are managed by federal government authorities and entities created by federal government authorities (except property owned by federal state-funded entities and autonomous entities) and federal treasury property, land rental fees, including revenue from sale of the right to enter into leasehold agreements on federal lands (except land plots owned by federal state-funded entities and autonomous entities), in the category of indicators that describe the effectiveness (performance) of using state property.

Semantically, this should include also revenue from sale of shares and other forms of stakeholding, federal lands, to which state ownership is delimited, that are in use by federal state-funded entities and autonomous entities, and all others that are in state ownership, although under the adopted indicator framework they also may be attributed to indicators that describe the turnover of federally owned property as set forth in sections on privatization and redistribution of such property between various levels of governance.

As to indicators of privatization of federally owned property, they are more focused on measuring changes in the effectiveness of the privatization process as opposed to indicators that describe the process of state property management.

Besides general indicators of federal budget revenue from sale of shares and other forms of stakeholding that are in state ownership, as well as the number of business entities whose shares (participatory share) are sold (with breakdown into majority and state-held blocking stakes), and FSUEs transformed into JSCs, the two latter indicators are compared with the number of business entities whose shares were offered for sale in the period under review, and unitary enterprises for which terms of privatization were set during the reporting year (or the number of enterprises included in the forecast plan (program) of privatization), respectively. Similar is indicator of the share of sold federally owned property of the number of federally owned property included in the privatization program and put up for sale. The technological aspect of the privatization process is reflected by the sole indictor of a share of federally owned property sold via electronic auctions of the total number of federally owned property that are included in the privatization program and sold during the current year. This section also contains an indicator of the total number of integrated entities whose formation was completed during the reporting year.

Indicators of the redistribution of federally owned property between various levels of public legal entities are represented according to the number and the book value of real property transferred from federal ownership into ownership of subjects of the Russian Federation and into ownership of municipalities and received from these levels of public power. For land plots, similar indicators of transfer and receipt according to absolute quantity, space and value are presented in the section on federal real property management, indicating to where such transfer goes according to indicators of quantity and space (into ownership of subjects of the Russian Federation and municipalities, legal entities or individuals according to the results of sale).

Let's take a look at the first, most general data obtained from the new indicator framework for the performance measurement of state property 
management that describe the scope of state ownership of respective economic entities.

Prior to making analysis, note that the Rosstat data rely on the legal entities typology described in the Civil Code of the Russian Federation in effect. All the legal entities were initially divided into for-profit and not-for-profit organizations according to whether profit-making is their primary objective

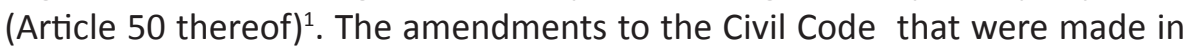
2014 complemented the previous division of legal entities with their classification according to the right to membership thereof (Article 65.1 thereof). If the founders (members) of legal entities have the right and if their supreme authority is general meeting of members, such organizations are deemed to be corporate legal entities (corporations). Unitary legal entities are legal entities whose founders neither become members nor acquire the right of membership thereof.

So, according to the most recent Rosstat data, Russia had a total of 65,600 economic entities that were in state ownership by the start of 2016 . The overwhelming majority of them $(57,400$, or $87.5 \%)$ were classified as notfor-profit organizations. Domination of unitary legal entities $(61,000)$ that accounted for $93 \%$ of all the analyzed population of legal entities was obvious, too (Table 3).

Table 3

NUMBER OF ECONOMIC ENTITIES THAT ARE IN STATE OWNERSHIP, ACCORDING TO LEGAL STATUS AS OF 1 JANUARY 2016

\begin{tabular}{|c|c|c|c|c|c|c|c|c|c|c|}
\hline \multirow[b]{3}{*}{ Total } & \multicolumn{5}{|c|}{ For-profit organizations } & \multicolumn{5}{|c|}{ Not-for-profit organizations } \\
\hline & \multirow[b]{2}{*}{ total } & \multicolumn{3}{|c|}{ corporate } & \multirow{2}{*}{$\begin{array}{c}\text { unitary } \\
\text { (unitary } \\
\text { enter- } \\
\text { prises) }\end{array}$} & \multirow[b]{2}{*}{ total } & \multirow[b]{2}{*}{$\begin{array}{l}\text { corpo- } \\
\text { rate }\end{array}$} & \multicolumn{3}{|c|}{ unitary } \\
\hline & & total & $\begin{array}{c}\text { busi- } \\
\text { ness } \\
\text { entities }\end{array}$ & others & & & & total & entities & others \\
\hline 65587 & 8216 & 3932 & $3888^{*}$ & $43^{* *}$ & 4284 & 57371 & $667 * * *$ & 56704 & $\begin{array}{c}56693 \\
* * * *\end{array}$ & $11 * * * * *$ \\
\hline
\end{tabular}

* including 3186 joint-stock companies (2254 public JSCs and 932 non-pubic JSCs) and 702 limited liability companies (LLCS);

** including 1 production co-operative and 42 other legal entities as for-profit organizations $^{2}$;

*** including 510 associations (unions), 153 condominiums and 4 consumer co-operatives;

**** including 40455 entities created by subjects of the Russian Federation, and 16194 entities created by the Russian Federation, as well as 2 state academies of sciences ${ }^{3}$ and 42 private entities;

***** including 10 foundations and 1 public legal entity as government-owned company ${ }^{4}$. Sources: www.gks.ru, 20 March 2016, own calculations.

1 A basic characteristic for not-for-profit organizations is that profit is not allotted between the members thereof.

2 Besides economic entities, unitary enterprises and production co-operatives, the Civil Code considers business and economic partnerships, farm households as for-profit organizations, however, their relationship with state ownership appears to be doubtful.

3 The breakdown into just 2 state academies of sciences among the entire bulk of entities raises questions because even after the recent reorganization of the Russian Academy of Sciences (RAS) that since 2013 has embraced the Russian Academy of Medical Sciences (RAMS) and the Russian Academy of Agricultural Sciences (RAAS), there are another 3 state academies of sciences, namely the Russian Academy of Education (RAE), the Russian Academy of Architecture and Construction Sciences (RAACS), the Russian Academy of Arts (RAA).

4 This legal status is represented only by Russian Highways (Avtodor), a nation-wide operator of the federal road network, that is intended to deliver public services and exercise other powers within the public road framework though federal property employment on a trust management basis. 
Considering the situation in greater detail, it is evident that the category of entities (56,700 units or $86.4 \%$ ) prevails among economic entities that are in state ownership, among which entities created by subjects of the Russian Federation can be distinguished, i.e., at the regional level $(40,500$ units or $61 / 7 \%)$, and entities created by the Russian Federation, i.e., at the federal level (16,200 units or $24.7 \%)$. In terms of quantity, the next two categories of organizations are largely outnumbered by entities: the share of unitary enterprises $(4,300)$ was only $6.5 \%$, and that of business entities $(3,900)$ stood at $5.9 \%$. Other legal statuses account for a bit more than $1 \%$ of all the economic entities that are in state ownership.

We now compare their structure according to levels of public ownership (Table 4).

Table 4

\section{NUMBER OF ECONOMIC ENTITIES THAT ARE IN STATE OWNERSHIP, ACCORDING TO LEGAL STATUS AND PUBLIC OWNERSHIP LEVEL AS OF 1 JANUARY 2016}

\begin{tabular}{|c|c|c|c|c|c|c|c|c|}
\hline \multirow[b]{2}{*}{ Total } & \multicolumn{4}{|c|}{ Federal property } & \multicolumn{4}{|c|}{$\begin{array}{l}\text { Property owned by subjects } \\
\text { of the Russian Federation }\end{array}$} \\
\hline & $\begin{array}{l}\bar{\pi} \\
\stackrel{\pi}{0}\end{array}$ & 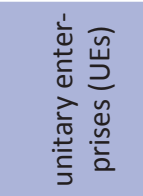 & 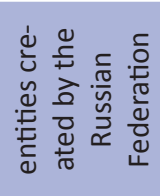 & 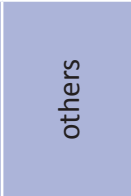 & $\begin{array}{l}\bar{\pi} \\
\stackrel{\pi}{0} \\
+0\end{array}$ & 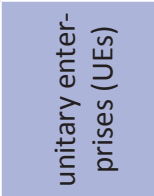 & 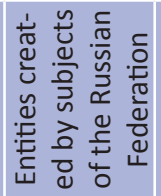 & $\begin{array}{l}\frac{n}{2} \\
\frac{\omega}{ \pm}\end{array}$ \\
\hline 65587* & 19786 & $1536 / 48^{* *}$ & 16194 & $2056 * * *$ & 45285 & $2748 / 111^{* *}$ & 40455 & 2082 \\
\hline
\end{tabular}

* including 516 organizations that are managed jointly by the Russian Federation and subjects thereof $(0.8 \%$ of the total number);

** the denominator includes the number of unitary enterprises with the right of operational management (state-owned enterprises) that are included in the total number;

*** including 1557 joint-stock companies (JSCs) whose shares are the property of the federal government.

Sources: www.gks.ru, 20 March 2016, own calculations.

Entities that are the property of subjects of the Russian Federation account for more than $69 \%$ of the total entities that are in state ownership, and entities that are in federal ownership make up about $30 \%$. Entities prevail at both levels, however, there are more of them at the regional level $(89.3 \%$ versus $81.8 \%$ at the federal level). By contrast, unitary enterprises $(7.8 \%$ versus $6.1 \%)$ are bigger in number among entities that are the property of the federal government. However, the largest differences are seen is in the share of other economic entities that are comparable in terms of absolute number at both levels. Their share at the federal level is almost 2.3 times that at the regional level (10.4\% versus $4.6 \%)$.

While the overwhelming majority of SUEs at both levels are enterprises with self-management rights and the share of enterprises with the right of operational management (state-owned) is not more than $3-4 \%$, there are much more differences in the structure of government entities (Table 5).

State-funded entities (about 23,900, or 59.1\%) prevail among entities created by subjects of the Russian Federation, and state-owned entities (more than 12,000 , or $74.3 \%$ ), accounting for $30 \%$ with comparable quantity at the regional level, prevail among entities created by the Russian Federation. Autonomous entities make up the smallest groups at both levels. At the regional level, however, they occupied a certain niche due to both absolute number (more than 4,400 units), outnumbering federal publicly funded enti- 
ties (FPFIs), and the share (10.9\%), whereas the share of autonomous entities is miniscule (less than 1\%) at the federal level.

Table 5

\section{NUMBER OF GOVERNMENT ENTITIES ACCORDING TO PUBLIC OWNERSHIP LEVEL AND TO TYPE AS OF 1 JANUARY 2016}

\begin{tabular}{|c|c|c|c|c|c|c|c|c|}
\hline \multirow[b]{2}{*}{ Total } & \multicolumn{4}{|c|}{ Entities created by the Russian Federation } & \multicolumn{4}{|c|}{$\begin{array}{l}\text { Entities created by subjects } \\
\text { of the Russian Federation }\end{array}$} \\
\hline & $\stackrel{\bar{T}}{\stackrel{0}{+}}$ & 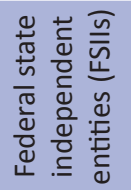 & 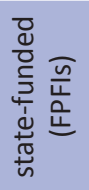 & 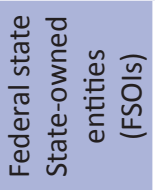 & 范 & 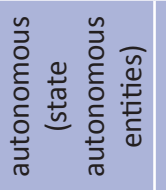 & 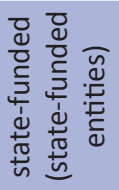 & 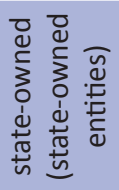 \\
\hline $6693 *$ & 16194 & 141 & 4024 & 12029 & 40455 & 4429 & 23891 & 12135 \\
\hline
\end{tabular}

* including 2 state academies of sciences and 42 private entities.

Source: www.gks.ru, 20 March 2016.

The Rosstat data do not allow for a comprehensive analysis of the structure of business entities in contrast to government entities and unitary enterprises (Table 6). At the regional level no information is available on the number of JSCs according to the size of a state-held stake, not to mention a lack of information on limited liability companies (LLCS) and JSCs according to public status.

\section{JOINT-STOCK COMPANIES WHOSE SHARES ARE THE PROPERTY OF THE FEDERAL GOVERNMENT, ACCORDING TO SIZE OF A STAKE HELD BY THE FEDERAL GOVERNMENT AS OF 1 JANUARY 2016}

\begin{tabular}{|c|c|c|c|c|c|c|c|c|c|}
\multicolumn{2}{|c|}{ Total } & \multicolumn{2}{c|}{$\begin{array}{c}\text { less } \\
\text { than } 25 \%\end{array}$} & \multicolumn{2}{c|}{$\begin{array}{c}\text { more than } 25 \% \\
\text { up to } 50 \%\end{array}$} & \multicolumn{2}{c|}{$\begin{array}{c}\text { more } \\
\text { than } 50 \%\end{array}$} & \multicolumn{2}{c}{$\begin{array}{c}\text { Special right to partake in } \\
\text { corporate governance } \\
\text { ("golden share") }\end{array}$} \\
\hline units & $\%$ & units & $\%$ & units & $\%$ & units & $\%$ & units & $\%$ \\
\hline 1557 & 100.0 & $567 *$ & 36.4 & 174 & 11.2 & 816 & 52.4 & $88^{* *}$ & $5.65^{* *}$ \\
\hline
\end{tabular}

* the value obtained by calculation;

** it is not quite clear whether this number includes JSCS in which the "golden share" is exercised together with a state stakeholding, accordingly, the share of such companies is shown as a percentage of the total number of JSCs whose shares are the property of the federal government.

Sources: www.gks.ru, 20 March 2016, own calculations.

As to the group of JSCs with state participation at the federal level (1557), it (the group) is comparable with the number of FSUEs (1536) and characterized by prevalence of companies in which the state holds more than $50 \%$, which allows for gaining a full majority control (52.4\% of total JSCs). No breakdown is made for the group of JSCs that are fully owned by the state $(100 \%)$. The share of companies in which the state has a minority stakeholding ( $25 \%$ or less) is small ( $36.4 \%$ of all the JSCs). Companies in which the state had instruments of partial corporate control such as blocking shareholding (from $25 \%$ to $50 \%$ ) and the special right to partake in corporate governance ("golden share") accounted for about $11 \%$ and $5.7 \%$ of JSCs, respectively.

Moving to the matter of specialization of economic entities that are in state ownership, note that they are represented mostly by types of activity that are related to performing the conventional set of public functions. The top-3 types of economic activity according to a respective classifier (All-Russia Classifier of Economic Activities (OKVED)) included public administration and military defence, social insurance $(17,600$ units or $26.8 \%)$, healthcare and social ser- 
vice $(15,700$ units or $24 \%)$, education $(11,600$ units or $17.6 \%)$. In total, they accounted for more than $2 / 3$ of all the economic entities.

In terms of quantity (more than 1,000 units), note also real-estate operations, lease holding and delivery of services $(7,700$ units, including research and development, 2,200 units), delivery of other utility, social and personal services $(4,300$ units, including organization of recreational and entertainment activities, cultural and sporting activities, 4,000 units), agriculture, hunting and forestry (about 2,500 units), manufacturing enterprises $(2,100$ units, including publishing and printing and reproduction of recorded media, 1,200 units), transport and communications (1,500 units).

Note, however, that classification according to the OKVED is of little help in understanding how economic entities really function in Russia's economy, including those that are related to state property. It would be sufficient to cite an example of combining research and development with real estate operations within a type of activity. To gain a better understanding of the place and the role of economic entities in state ownership, one should take a look at the structure of federal government entities and unitary enterprises according to type of economic activity and to their departmental affiliation (Tables 7 and 8$)$.

Table 7

BREAKDOWN OF FEDERAL GOVERNMENT ENTITIES AND UNITARY ENTERPRISES BY TYPE OF ECONOMIC ACTIVITY AS OF 1 JANUARY 2016

\begin{tabular}{|c|c|c|c|c|c|}
\hline \multicolumn{3}{|c|}{ Federal government entities } & \multicolumn{3}{|c|}{ Federal State Unitary Enterprises } \\
\hline type of activity & units & $\%$ & type of activity & units & $\%$ \\
\hline $\begin{array}{l}\text { public administration } \\
\text { and military defence, } \\
\text { social insurance }\end{array}$ & 10866 & 67.1 & $\begin{array}{l}\text { real-estate operations, lease } \\
\text { holding and delivery of services }\end{array}$ & $\begin{array}{l}532 / \\
289 *\end{array}$ & $\begin{array}{l}34.6 / \\
18.8^{*}\end{array}$ \\
\hline $\begin{array}{l}\text { real-estate opera- } \\
\text { tions, lease holding and } \\
\text { delivery of services }\end{array}$ & $\begin{array}{l}1561 / \\
1072^{*}\end{array}$ & $\begin{array}{l}9.6 / \\
6.6^{*}\end{array}$ & manufacturing enterprises & 293 & 19.1 \\
\hline education & 1438 & 8.9 & agriculture, hunting and forestry & 210 & 13.7 \\
\hline Total & 13865 & 85.6 & Total & 1035 & 67.4 \\
\hline
\end{tabular}

* the denominator includes the number and the share of FGEs and FSUEs involved in research and development, that make up the total number of economic entities that fall under the "real-estate operations, lease holding and delivery of services" type of activity;

Sources: www.gks.ru, 20 March 2016, own calculations.

The presented data is a good illustration of the differences between FGEs and FSUEs.

FGEs are dominated by types of activity related to performing the conventional set of public functions (public administration and military defence, social insurance (about 10,900 units or more than $67 \%$ ), real-estate operations, lease holding and delivery of services (about 1,600 units or $9.6 \%$ ), education (more than 1,400 units or $8.9 \%$ )), which is much in common with the structure of the entire population of economic entities in state ownership. The difference is that the top-3 includes a type of activity such as real-estate operations, lease holding and delivery of services (instead of healthcare and social service) that has little to do with public functions, but it is represented more than $2 / 3$ by research and development in the case of FGEs.

The structure of FSUEs is largely of production and business nature. Their top-3 types of activity make up the above mentioned real-estate operations, lease holding and delivery of services (532 units or $34.6 \%$, of which, however, more than a half ( 289 units) are involved in research and development), 
manufacturing enterprises (293 units or more than 19\%), agriculture and forestry (together with hunting) (210 units or $13.7 \%$ ).

The foregoing differences between FGEs and FSUEs are seen mostly when their departmental affiliation is analyzed (Table 8).

\section{BREAKDOWN OF FEDERAL GOVERNMENT ENTITIES AND UNITARY ENTERPRISES ACCORDING TO FEDERAL GOVERNMENT AUTHORITIES (FGO) THEY ARE AFFILIATED WITH, IN ACCORDANCE WITH THE NATIONAL CLASSIFIER OF GOVERNMENT ENTITIES AND ADMINISTRATION AS OF 1 JANUARY 2016}

\begin{tabular}{|c|c|c|c|c|c|}
\hline \multicolumn{3}{|c|}{ Federal government entities } & \multicolumn{3}{|c|}{ Federal state unitary enterprises } \\
\hline federal government authority & units & $\%$ & type of activity & units & $\%$ \\
\hline Ministry of Internal Affairs (MIA) & 2463 & 15,2 & $\begin{array}{l}\text { Ministry of Industry } \\
\text { and Trade }\end{array}$ & 194 & 12,6 \\
\hline Ministry of Justice & 2072 & 12,8 & $\begin{array}{l}\text { Federal Agency } \\
\text { for Scientific } \\
\text { Organizations (FASO) }\end{array}$ & 164 & 10,7 \\
\hline $\begin{array}{l}\text { Ministry of Civil Defence Affairs, } \\
\text { Emergencies, and Liquidation } \\
\text { of Consequences of Natural } \\
\text { Disasters (EMERCOM) }\end{array}$ & 1262 & 7,8 & Ministry of Agriculture & 124 & 8,1 \\
\hline Ministry of Finance & 1250 & 7,7 & Ministry of Defence & 107 & 7,0 \\
\hline Total & 7047 & 43,5 & Total & 589 & 38,3 \\
\hline
\end{tabular}

Sources: www.gks.ru, 20 March 2016, own calculations.

FGEs comprises mostly of entities (more than 1,000) managed by 4 federal government authorities that are directly related to performing public functions: the Ministry of Internal Affairs (MIA) (about 2,500 units or more than $15 \%$ ), the Ministry of Justice (Minjust) (about 2,100 units or $12.8 \%$ ), the EMERCOM (about 1,300 units or 7,8\%) and the Ministry of Finance (Minfin) $(1,2500$ units or $7.7 \%)$. FSUEs are represented mostly by groups of enterprises (more than 100 units) that are managed by the Ministry of Industry and Trade (Minpromtorg) (194 units or 12.6\%), the Federal Agency for Scientific Organizations (FASO) (164 units or 10.7\%), the Ministry of Agriculture (Minselkhoz) (124 units or more than 8\%) and the Ministry of Defense (Minoborony) (107 units or 7\%). They are lesser in number among government authorities: FGEs were managed by 76 FGOs, including ministries, agencies, services, administrations, and FSUEs were managed by 58 entities ${ }^{1}$.

Such data on specialization and departmental affiliation of federal government entities and unitary enterprises are in sharp contrast to the lack of such data for business entities with state participation and for level of subjects of the Russian Federation in general.

There is information available concerning all the economic entities that are in state ownership at the regional level. More than $40 \%$ of the total number $(65,600$ entities) account for Moscow $(5,900)$, St. Petersburg $(4,000)$, Moscow Region (2,000), as well as another 11 regions (Sverdlov Region, Dagestan, Krasnodar Territory, Samara Region, Tatarstan, Tyumen Region (including autonomous districts), Bashkortostan, Krasnoyarsk Territory, Nizhny Novgorod Region and Rostov Region, Altai Territory), each having

1 An important thing is that some entities and enterprises are managed by government authorities (agencies and services) that in turn are managed by ministries. For example, the Federal Tax Service (FTS) is managed by the Ministry of Finance (MinFin), and the Federal Agency for Fishery (Rosrybolovstvo) is managed by the Ministry of Agriculture (Minselkhoz). 
1 to 1,700 of such entities. Almost all of them (except Dagestan and Altai Territory) are the most economically developed regions. By contrast, there is a small number of regions in Siberia and the Far East, where the total number of economic entities in state ownership was not more than 300 per subject of the Russian Federation (the Republic of Altai, Magadan Region and the Jewish Autonomous Region, Chukotka).

In summary, the following is worth noting.

First, transition to providing data in terms of legal forms, which was not the case under the old indicator framework for public sector monitoring, as well as a special focus on property (real estate, land, stakes (interest) of any size) given the value and liquidity thereof is the main novelty that the new 2015 framework offers, although these indicators were presented in part in reports of the Federal Agency for State Property Management and other agencies, and in accounts of budget expenditure and revenue.

At the same time, transition from sale of property or assets thereof to sale of business units has been announced as a new approach under the State Program "Federal Property Management" in effect until 2018. ${ }^{1}$ Following the same logic, both the public sector as the nucleus of state property and the subject to management make up an integrated population of businesses that are subject to public management and property control. The Community Board of the Ministry of Economic Development of Russia held a meeting late in March 2016 , in which the implementation of the privatization program in effect was discussed and CB members pointed to the need of developing a methodology for measuring the share of state participation in the economy ${ }^{2}$. It is recognized that the public sector monitoring that was in effect until 2015 as an integral part of the Russian economy showed directly the size of public sector's share for a wide range of natural and financial indicators. The issue is whether the measurement of its share of the economy as a whole was correct.

Second, the issue of measuring the share of state participation in the economy is still relevant.

The gaps in the public sector definition that was previously employed for statistical purposes were related to incomplete coverage of options of exercising property control by the state towards acting economic entities that was attained in case of disparities in stakeholding and voting shares, employing indirect control schemes or involving other organizations etc. ${ }^{3}$ The foregoing have been partially tackled by the new indicator framework that accounts all business entities with state participation of any size, which, however, may result in overestimation of the degree of property control by the state by way of including minority stakes (interest). Further steps towards this aspect are inevitably related to a breakdown within the category of business entities.

1 The State Program was adopted by Russian Government's Executive Order No. 327of 15 April 2014 in replacement for the state program with the same title that was in effect for a period of about 14 months.

2 www.economy.gov.ru, 01 April 2016.

3 For example, in Gazprom's charter capital it is controlled indirectly though other companies, where it is acting directly as shareholder (Rosneftegaz and Rosgazifikatsiya), even after a scheme of bringing the state stakeholding to a controlling size was implemented in 20042005. A more detailed description of the challenges of attributing economic entities to the public sector and defining its limits is made in Russian economy in 2007. Trends and outlooks (Issue 29). M., IET, March 2008, pp. 485-486, Russian economy in 2010. Trends and outlooks (Issue 32). M., Gaidar Institute, 2011, pp. 404-406. 
However, the exclusion of the previously accounted category as companies, in which more than a half of the capital are owned by business entities that were attributed to the public sector, is rather a step backwards, especially given the formation of numerous entities integrated on the basis of SUES corporisation and the contribution of shares to holding companies' charter capital, not to mention more sophisticated schemes of non-transparency with regard to subsidiaries of and affiliates with business groups established around public sector organizations, where control is exercised indirectly through various levels (lower-tier subsidiaries etc.).

Still unclear is the point about government-owned corporations (GOCs) whose basic characteristic, regardless their name, is that they fall under the category of not-for-profit organizations to whose property the state has no ownership rights whatsoever (including shares, as is the case with OAK and OSK). The observed population includes government-owned Rosavtodor, foundations, as well as entities with an "exotic" legal status (production and consumer co-operatives, associations (unions), partnerships, private entities), whose reference to state ownership raises questions.

Third, the population of economic entities that are in state ownership, was found to be bigger by the start of 2016 compared to the mid-2014 data provided by the public sector monitoring, which might be expected due to the foregoing changes in the accounting methodology. At the same time, there was increase in the number (entities) or stabilization (unitary enterprises) for comparable categories of entities.

Overall, the characteristics of economic entities that are in state ownership come down to the following:

- domination of unitary legal entities that are classified as not-for-profit organizations, mostly government entities;

- strictly in terms of quantity, the regional level prevails over the federal level;

- there is a bigger share of entities at the regional level while there is a bigger share of unitary enterprises and especially other economic entities, most of which are JSCs, at the federal level;

- enterprises with self-management rights dominate among unitary enterprises at both levels, whereas the share of state-owned enterprises is insignificant;

- there are big differences in the level of public ownership in the category of government agencies: state-owned entities dominate at the federal level while state-funded prevail at the regional level, with a considerable share of autonomous ones;

- it is difficult to make a comprehensive assessment of the category of business entities due to a lack of relevant information that is reduced to a group of JSCS with state participation at the federal level, where a stakeholding (more than 50\%) in more than a half of the companies allows the state to exercise a majority control;

- economic entities that are in state ownership are specializing mostly in performing the traditional set of public functions (administration, security, education, healthcare, science);

- detailed analysis of the specialization and departmental affiliation of organizations at the federal level shows that entities and enterprises differ in that the latter are focused more on business and production activities. 
Fourth, a set of indicators (profit, amortisation, compensation for labour) that was announced for statistical survey contains preconditions for adequate assessment of a share of the economy that is controlled by public legal entities within the framework of approaches employed as part of the National Accounts framework for production calculation and distribution of GDP at various stages ${ }^{1}$.

Indeed, statistics enhancement on the basis of all the above mentioned reservations is a precondition for this. First of all, it is reasonable to refer to data collection as is the case with the data that the new indicator framework for the performance measurement of state property management should provide for the federal level, but this time for subjects of the Russian Federation. Today, besides the number of economic entities, at this level the framework is limited to indicators of re-allotment of land and real property among public authority levels and revenue to the budgets of subjects of the Russian Federation from sale of shares and other forms of stakeholding. There is a separate issue of propagating the respective statistical survey across the municipal level.

1 This aspect should be kept distinct from the widely used assessment of the load that the state puts on the economy, which is measured as the ratio of budget revenue (or expenditure) to GDP. 